\title{
SISTEM INFORMASI LAUNDRY MENGGUNAKAN METODE WATERFALL BERBASIS ANDROID PADA SIMPLY FRESH LAUNDRY
}

\author{
Muhamad Alda \\ STMIK Logika \\ Jl. K.L. Yos Sudarso Kota Medan Sumatera Utara 20116, Indonesia \\ muhamadalda9egmail.com
}

\begin{abstract}
The processing of laundry transaction data on Simply Fresh Laundry is still done conventionally. Simply Fresh Laundry is still using notes as a medium to record customer transactions. In this way, there are still some problems that occur, especially the time and the power spent in doing the transaction process becomes ineffective and efficient. The research aims to design and build an Android-based information system using the Waterfall method. The information system that is built can solve problems that occur regarding the transaction on Simply Fresh Laundry. This information system can help Simply Fresh Laundry in the processing of data laundry transactions quickly and easily and help customers to obtain information about the process of laundry through an Android smartphone. The information system is designed based on the steps found in the Waterfall method. While the process of building information system using Kodular application and Airtable database.
\end{abstract}

Keywords - Information System, Laundry, Waterfall Method, Android Smartphone

Abstrak - Proses pengolahan data transaksi laundry pada Simply Fresh Laundry masih dilakukan secara konvensional. Simply Fresh Laundry masih menggunakan nota sebagai media untuk mencatat transaksi yang dilakukan pelanggan. Dengan cara seperti ini, masih terdapat beberapa masalah yang terjadi,terutama wakt dan tenaga yang dikeluarkan dalam melakukan proses transaksi menjadi tidak efektif dan efisien. Penelitian ini bertujuan untuk merancang dan membangun sistem informasi berbasis android dengan menggunakan metode Waterfall. Sistem informasi yang dibangun dapat menyelesaikan permasalahan yang terjadi mengenai transaksi pada Simply Fresh Laundry. Sistem informasi ini dapat membantu Simply Fresh Laundry dalam melakukan pengolahan data transaksi laundry secara cepat dan mudah dan membantu pelanggan untuk memperoleh informasi mengenai proses laundry melalui smartphone android. Sistem informasi dirancang berdasarkan tahapan yang terdapat pada metode Waterfall. Sedangkan proses pembangunan sistem informasi menggunakan aplikasi Kodular dan database Airtable.

Kata Kunci : Sistem Informasi, Laundry, Metode Waterfall, Smartphone Android

\section{PENDAHULUAN}

Android merupakan salah satu smartphone yang perkembangannya sangat pesat, di Indonesia sendiri penggunaan smartphone semakin meningkat dari tahun ke tahunnya, tetapi tidak banyak orang yang benarbenar memanfaatkan smartphone secara maksimal. Kebanyakan orang hanya menggunakannya untuk sosial media dan hiburan semata [1]. Smartphone android memiliki fitur yang lengkap sehingga selain digunakan sebagai media hiburan,smartphone android dapat digunakan untuk pemenuhan kebutuhan informasi dan membantu dalam menyelesaikan pekerjaan dalam berbagai bidang.

Usaha laundry merupakan sebuah bisnis yang berkaitan dengan pelayanan jasa pencucian pakaian dengan mesin cuci maupun mesin pengering otomatis dan cairan pembersih serta pewangi khusus [2].

Simply Fresh Laundry merupakan salah satu usaha yang bergerak dibidang jasa pencucian pakaian di Kota Medan. Dalam melakukan proses transaksi, Simply Fresh Laundry masih menggunakan cara manual atau belum terkomputerisasi. Setiap ada pelanggan yang datang untuk mencuci pakaian, pegawai Simply Fresh Laundry menghitung berat pakaian tersebut dan besar biaya yang harus dibayarkan oleh pelanggan kemudian mencatatnya pada sebuah buku serta membuat nota pembayaran yang diberikan kepelanggan. Cara seperti ini masih kurang efektif dan efisien untuk dilakukan. Pegawai Simply Fresh Laundry membutuhkan waktu, biaya dan tenaga yang banyak untuk melakukan pencatatan data transaksi.

Tujuan dari penelitian ini adalah untuk membantu Simply Fresh Laundry dalam melakukan proses pengolahan data transaksi laundry dan membantu pelanggan dalam memperoleh informasi laundry dengan merancang sebuah sistem informasi berbasis android menggunakan aplikasi Kodular dan database Airtable 


\section{LANDASAN TEORI}

\section{A. Konsep Sistem Informasi}

Sistem informasi adalah sebuah sub sistem yang merupakan bagian dari sebuah sistem lain yang lebih besar. Sistem informasi tidak dapat dirancang dan dioperasikan secara terpisah dari sub sistem yang lain [3].

Sistem informasi memiliki beberapa komponen, antara lain [4] :

1. Blok Masukan (Input Block), data yang masuk ke dalam sistem informasi.

2. Blok Model (Model Block), blok yang akan memanipulasi data input.

3. Blok Keluaran (Output Block), keluaran yang merupakan informasi yang berkualitas.

4. Blok Teknologi (Technology Block),. Blok teknologi terdiri dari user (brainware), perangkat lunak (software), dan perangkat keras (hardware).

5. Basis Data (Database Block), basis data merupakan tempat data dikumpulkan yang tersimpan di perangkat keras komputer dan digunakan perangkat lunak untuk memanipulasinya.

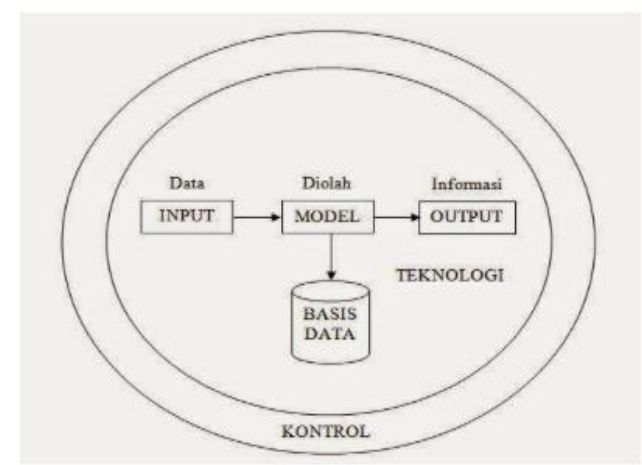

Gambar 1.Komponen Sistem Informasi

B. Metode Waterfall

Model pengembangan software yang diperkenalkan oleh Winston Royce pada tahun 70-an ini merupakan model klasik yang sederhana dengan aliran sistem yang linier. Keluaran dari tahap sebelumnya merupakan masukan untuk tahap berikutnya. [5]. Artinya setiap tahapan dalam metode ini dilakukan secara berurutan dan berkelanjutan [6] Jadi jika langkah satu belum dikerjakan maka tidak akan bisa melakukan pengerjaan langkah 2, 3 dan seterusnya [7].

\section{Konsep Android}

Android adalah sebuah sistem operasi untuk perangkat mobile berbasis linux yang mencakup sistem operasi, middleware dan aplikasi. Android menyediakan platform terbuka bagi para pengembang untuk menciptakan aplikasi mereka sendiri yang akan digunakan untuk bermacam peranti bergerak. [8].

Fitur - fitur yang terdapat pada android adalah sebagai berikut [9] :

a. Kerangka aplikasi: memungkinkan untuk menggunakan dan menghapus komponen yang tersedia.

b. Dalvik mesin virtual: mesin virtual digunakan secara optimal untuk perangkat telepon seluler.

c. Grafik: grafik di 2D dan grafis 3D berdasarkan pustaka OpenGL.

d. SQLite: sebagai database.

e. Mendukung media: audio, video, dan berbagai format gambar.

f. GSM, Bluetooth, EDGE, 3G, 4G dan WiFi (tergantung piranti keras)

g. Kamera, Global Positioning System (GPS), kompas, NFC dan accelerometer (tergantung piranti keras)

\section{METODOLOGI PENELITIAN}

Tahapan yang dilakukan dalam penelitian sesuai dengan tahapan yang terdapat pada metode Waterfall.

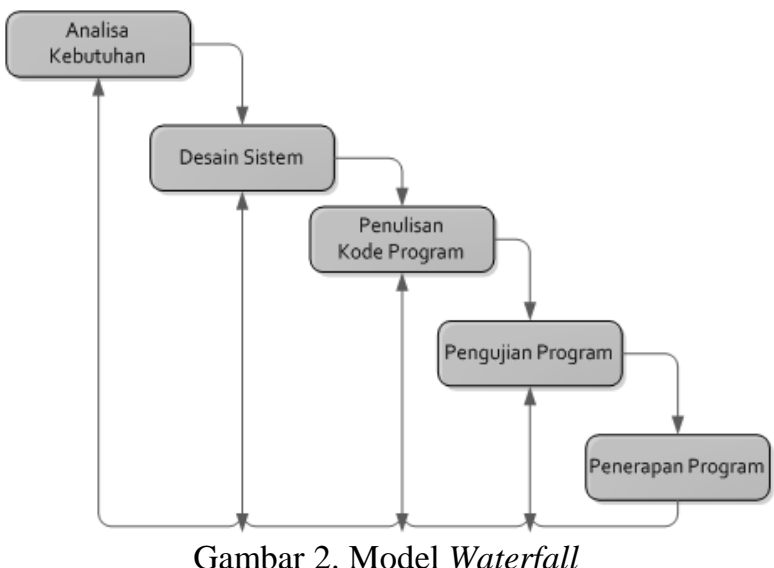

a. Analisa kebutuhan

Analisa kebutuhan merupakan langkah awal untuk menentukan desain sistem dengan menu-menu yang diperlukan oleh user untuk melakukan pembangunan sistem informasi.

b. Desain sistem

Desain merupakan tahap pembuatan rancangan dari sistem yang akan dibangun. Tools yang digunakan dalam membuat desain sistem ini adalah UML (Unified Modeling Languange) yang terdiri dari : Use Case Diagram, Activity Diagram, Sequence Diagram, serta Class Diagram.

c. Penulisan kode program.

Penulisan kode program merupakan tahapan menerjemahkan desain sistem ke dalam bentuk perintah-perintah yang dimengerti oleh komputer 
dengan menggunakan aplikasi Kodular dan database Airtable

d. Pengujian Program

Pada tahap ini semua proses input output diuji coba sehingga kemungkinan terjadi error dan bug dapat segera diketahui dan dilakukan perbaikan pada penulisan kode program.

e. Penerapan Program

Penerapan program merupakan tahapan terakhir dimana pengembang menerapkan sistem informasi yang telah selesai dibuat dan diuji sebelumnya.

\section{ANALISIS DAN HASIL}

A. Analisis Permasalahan

Sebelum melakukan tahapan perancangan, penulis terlebih dahulu melakukan analisis mengenai sistem yang sedang berjalan. Analisis yang dilakukan oleh penulis berfokus pada sistem transaksi pada Simply Fresh Laundry. Proses transaksi pada Simply Fresh Laundry masih dilakukan secara manual. Proses transaksi dilakukan dengan cara menulis pada sebuah nota penjualan kemudian nota tersebut diberikan kepada pelanggan. Selain itu, proses pencatatan laporan transaksi masih menggunakan sebuah buku. Berdasarkan proses tersebut, masih terdapat beberapa masalah atau kendala yang terjadi, antara lain :

1. Waktu,biaya dan tenaga yang dibutuhkan dalam melakukan proses pengolhan transaksi laundry menjadi tidak efektif dan efisien

2. Sulitnya dalam membuat laporan transaksi

3. Membutuhkan tempat penyimpanan secara fisik, sehingga menyebabkan besarnya biaya yang dikeluarkan pengadaan tempat penyimpanan

4. Pelanggan kesulitan dalam memperoleh informasi mengenai Simply Fresh Laundry dan mengenai proses laundry yang telah dikerjakan.

B. Analisis Kebutuhan Sistem

Berdasarkan hasil dari analisis sistem berjalan yang telah dilakukan, salah satu solusi yang dapat digunakan untuk menyelesaikan permasalahan tersebut adalah dengan merancang dan membangun sebuah sistem informasi berbasis android yang dapat digunakan untuk membantu Simply Fresh Laundry dalam melakukan proses pengolahan data transaksi dan membantu pelanggan dalam memperoleh informasi secara cepat dan akurat melalui smartphone android.

\section{Perancangan Sistem}

Tools yang digunakan dalam membuat rancangan sistem adalah Diagram UML (Unified Modeling Languange). UML (Unified Modeling Language) merupakan bahasa visual untuk pemodelan dan komunikasi mengenai sebuah sistem dengan menggunakan diagram dan teks-teks pendukung [10]

\section{Use Case Diagram}

Use Case diagram digunakan untuk menggambarkan interaksi apa saja yang bisa dilakukan user kepada sistem. Sistem informasi dibangun secara multiuser, sehingga sistem informasi ini dapat diakses oleh dua user yang berbeda yaitu pelanggan dan admin. Setiap user memiliki hak akses yang berbeda.

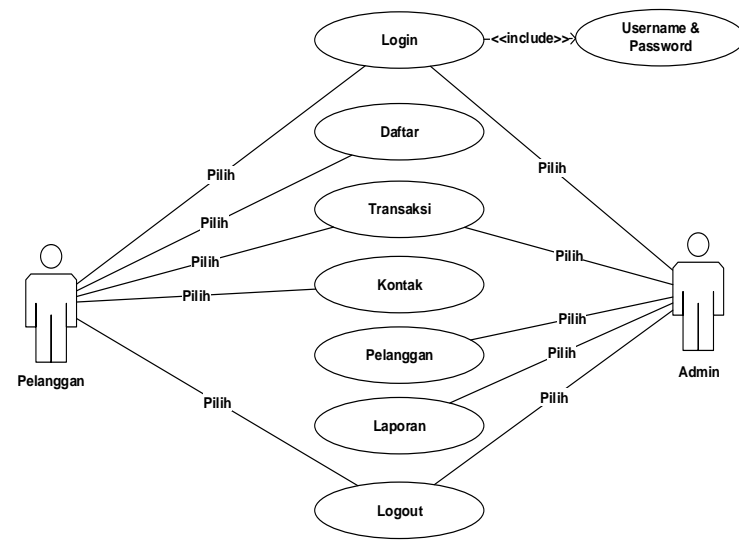

Gambar 3 Use Case Diagram Sistem Informasi Laundry

\section{Sequence Diagram}

Sequence Diagram menggambarkan bagaimana user melakukan interaksi dengan sistem informasi untuk mendapatkan informasi yang dibutuhkan.Sequence diagram pada sistem informasi laundry dibedakan menjadi dua jenis, yaitu sequence diagram pelanggan dan sequence diagram admin.

\section{a. Sequence Diagram Pelanggan}

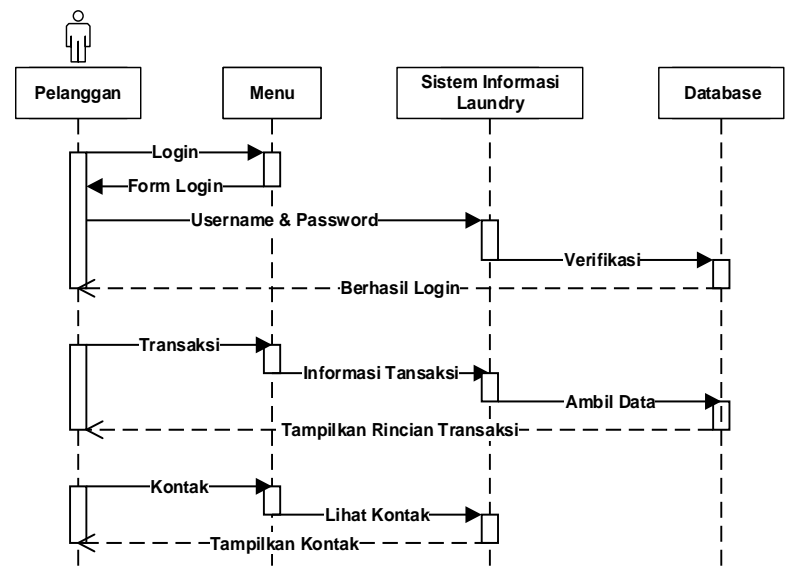

Gambar 4 Sequence Diagram Pelanggan 
b. Sequence Diagram Admin

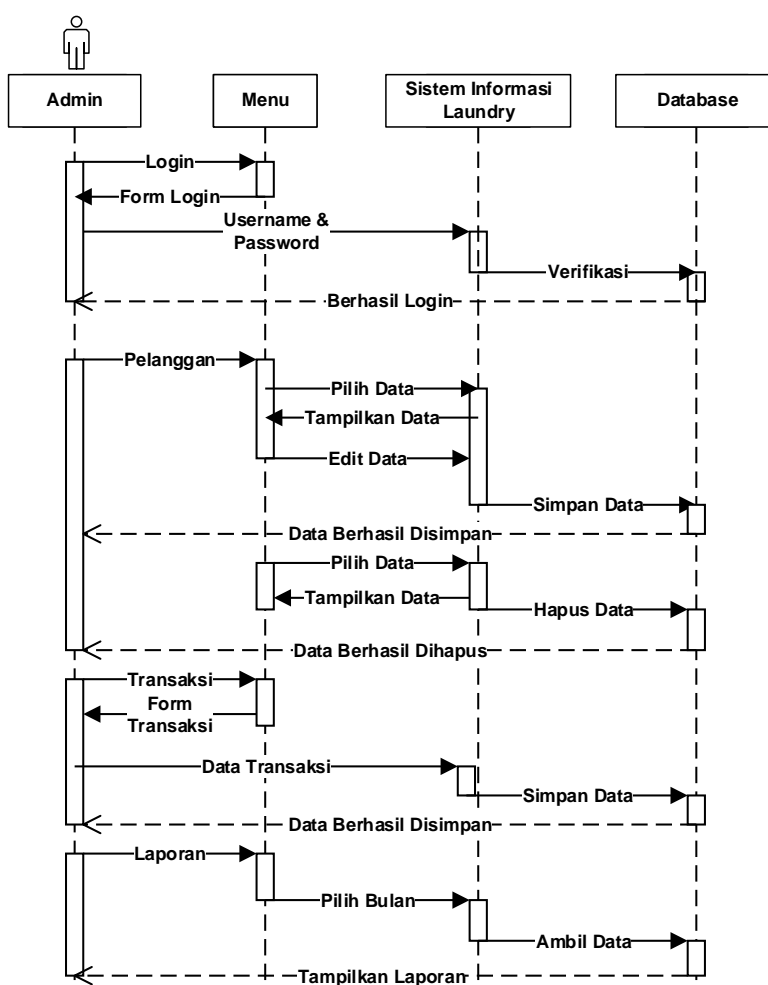

Gambar 5 Sequence Diagram Admin

\section{Activity Diagram}

Activity diagram atau disebut juga dengan diagram aktivitas, merupakan diagram yang menggambarkan aktivitas dari sebuah sistem, bagaimana sistem melakukan suatu aktivitas dalam menjalankan fungsi tertentu. Sama halnya seperti sequence diagram, activity diagram pada sistem informasi laundry terbagi menjadi dua jenis, yaitu activity diagram pelanggan dan activity diagram admin

a. Activity Diagram Pelanggan

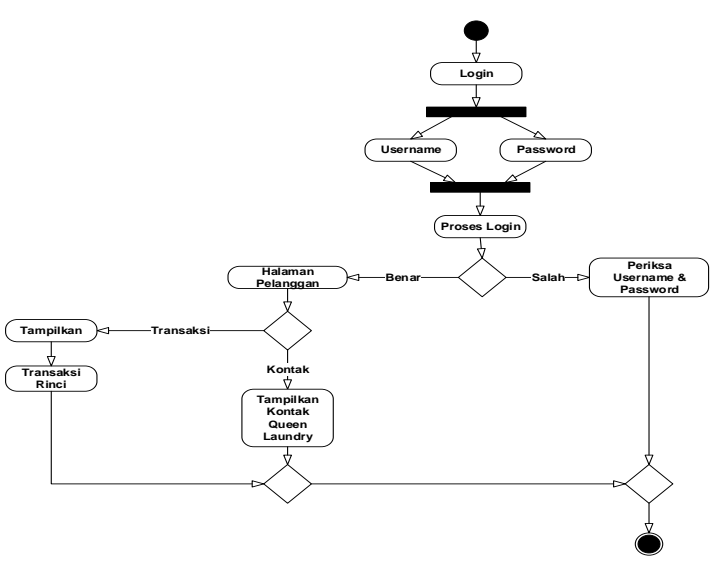

Gambar 6 Activity Diagram Pelanggan b. Activity Diagram Admin

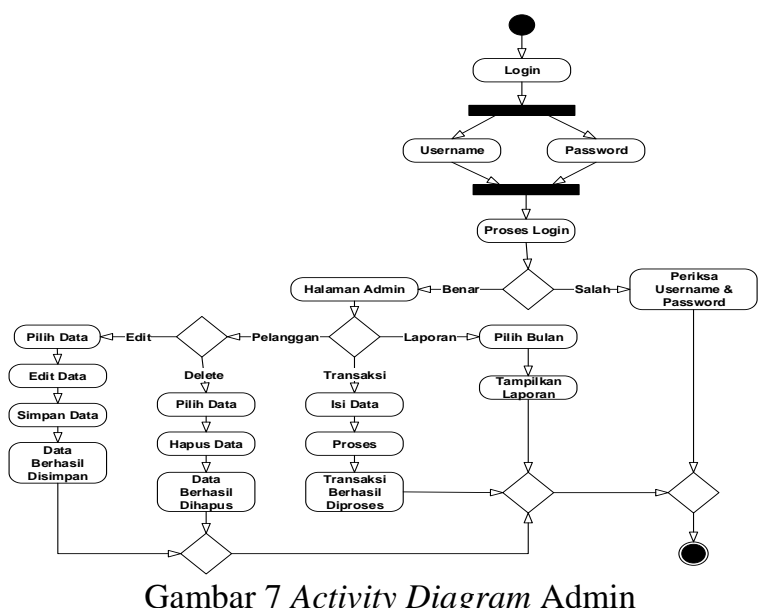

c. Class Diagram

Class Diagram merupakan diagram yang menggambarkan hubungan dari setiap class atau tabel yang terdapat pada database sistem informasi laundry. Class atau tabel pada sistem informasi laundry terdiri dari tabel admin, tabel user dan table transaksi

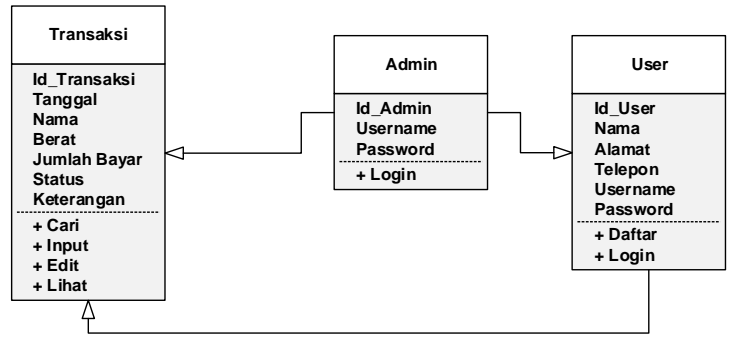

Gambar 8 Class Diagram Sistem Informasi Laundry

d. Implementasi Sistem

Halaman Login Pelanggan

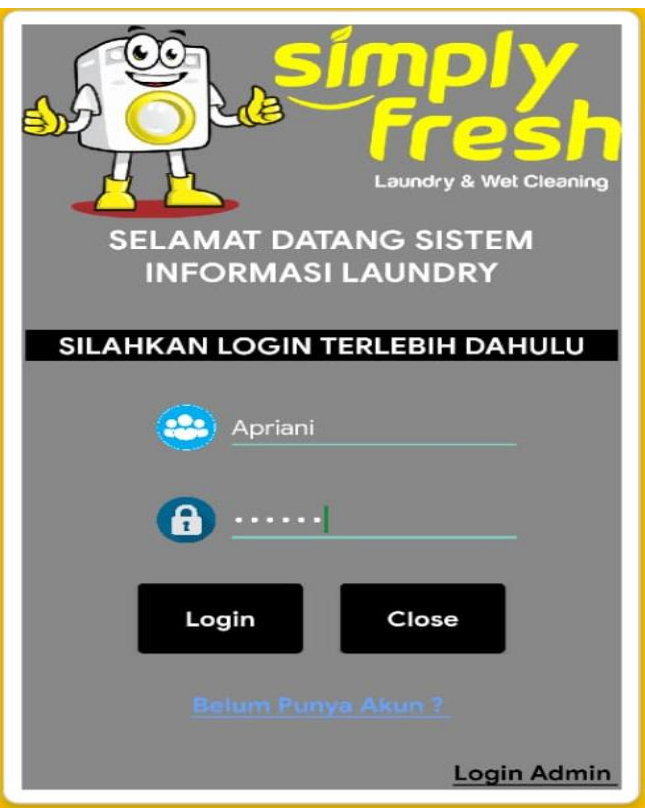

Gambar 9 Halaman Login Pelanggan 
Halaman Daftar Pelanggan

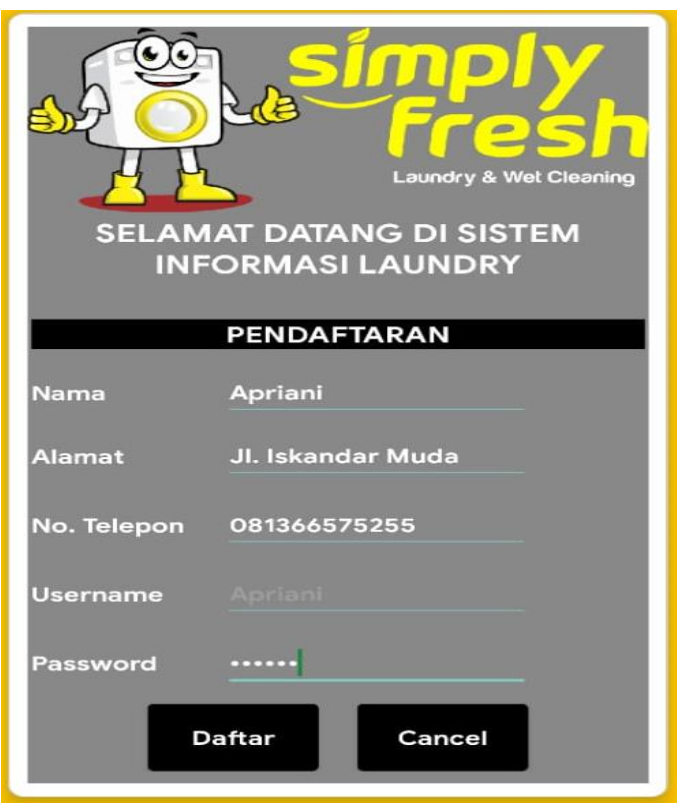

Gambar 10 Halaman Daftar Pelanggan

Halaman Menu Pelanggan

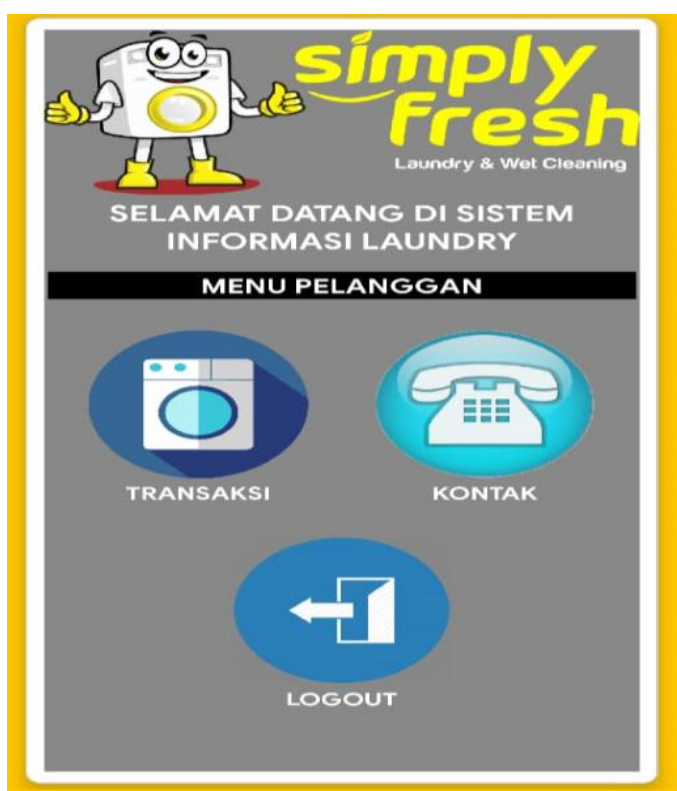

Gambar 11 Halaman Menu Pelanggan
Halaman Transaksi Pelanggan

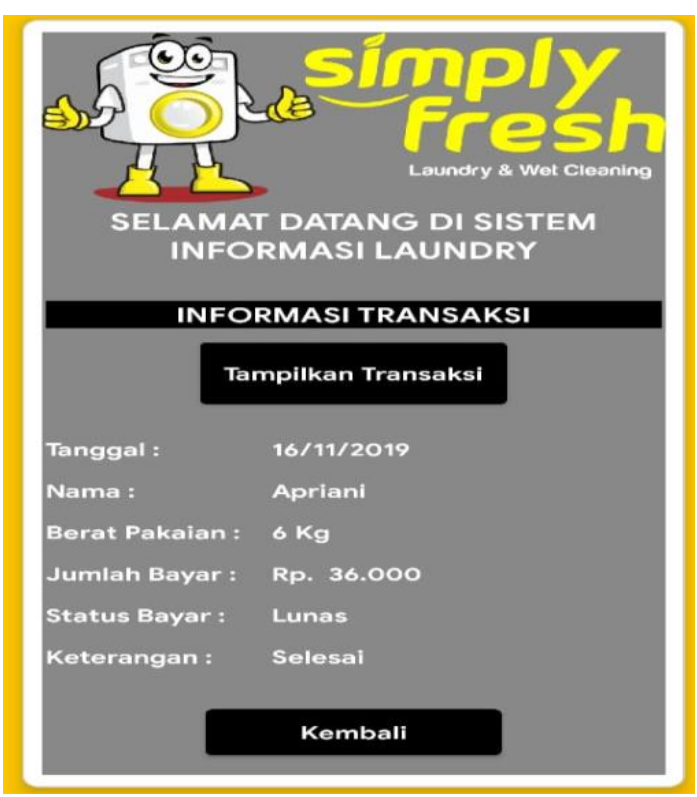

Gambar 12 Halaman Transaksi Pelanggan

Halaman Login Admin

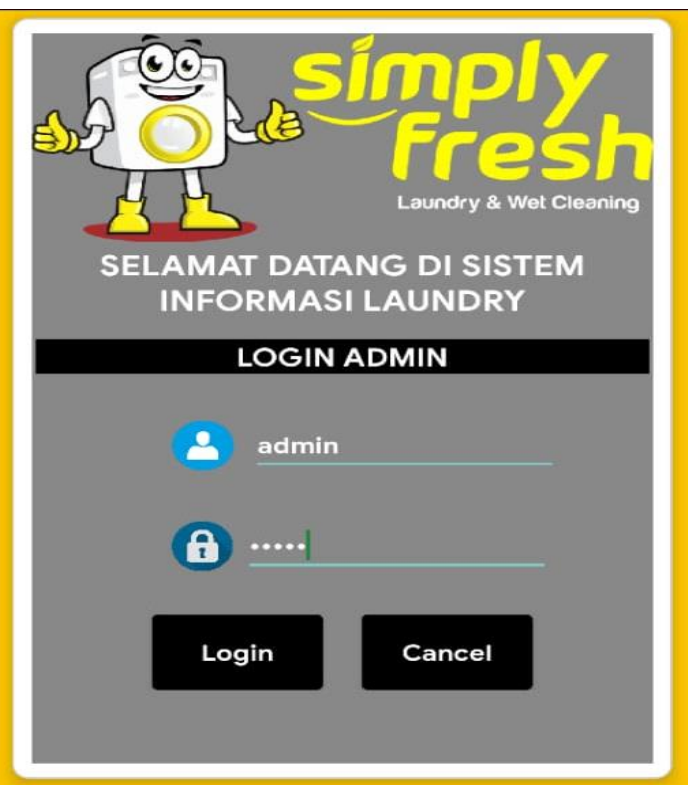

Gambar 13 Halaman Login Admin 
Halaman Menu Admin

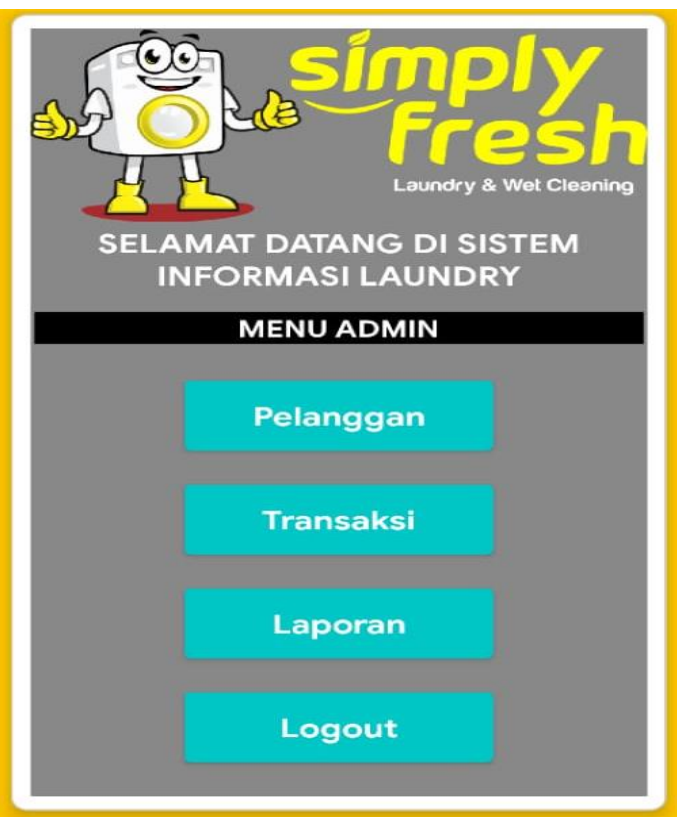

Gambar 14 Halaman Menu Admin

Halaman Data Pelanggan

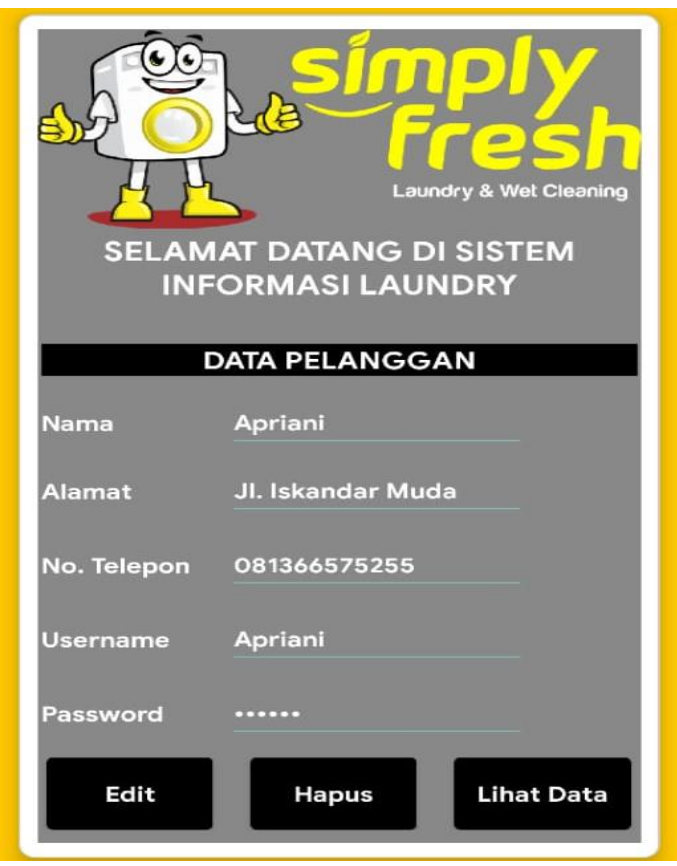

Gambar 15 Halaman Data Pelanggan
Halaman Transaksi

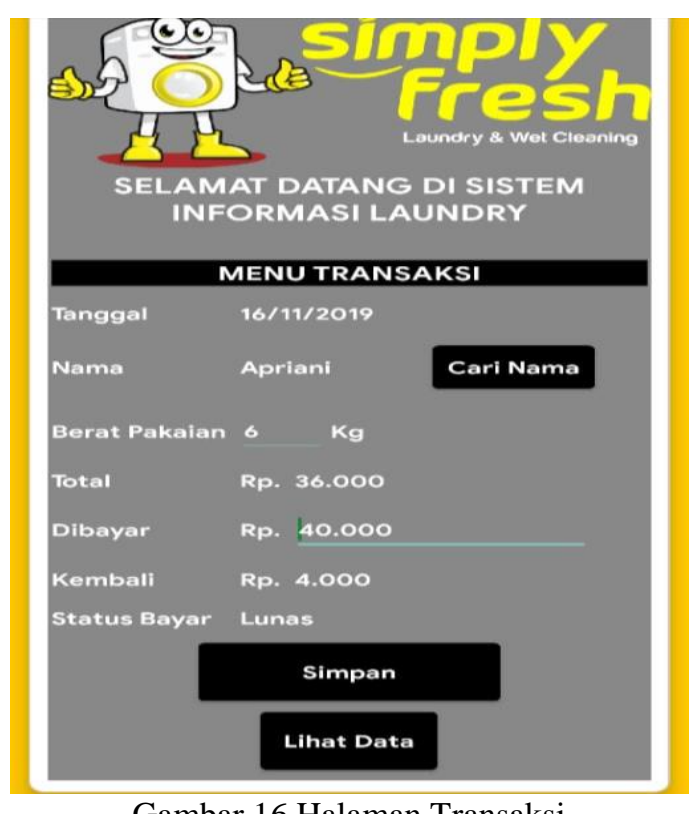

Gambar 16 Halaman Transaksi

Halaman Proses Transaksi

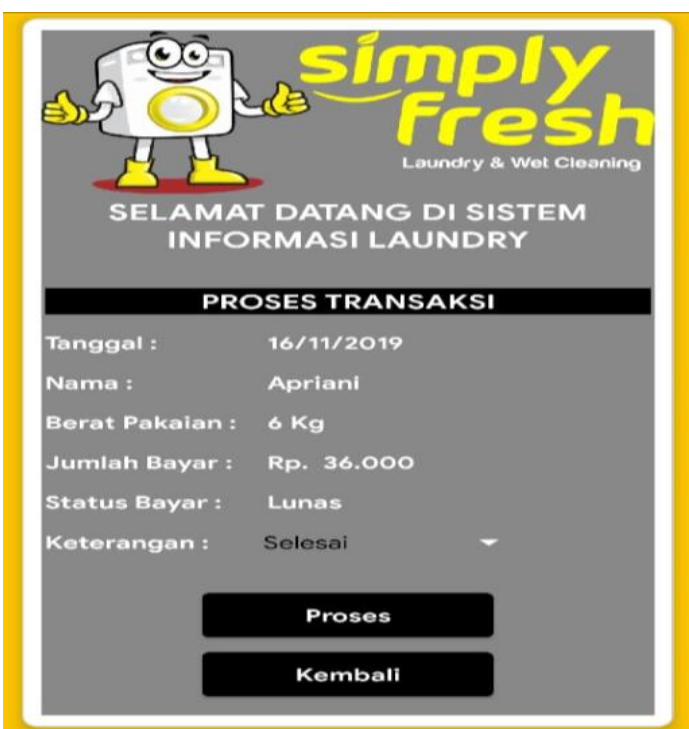

Gambar 17 Halaman Proses Transaksi

Halaman Laporan

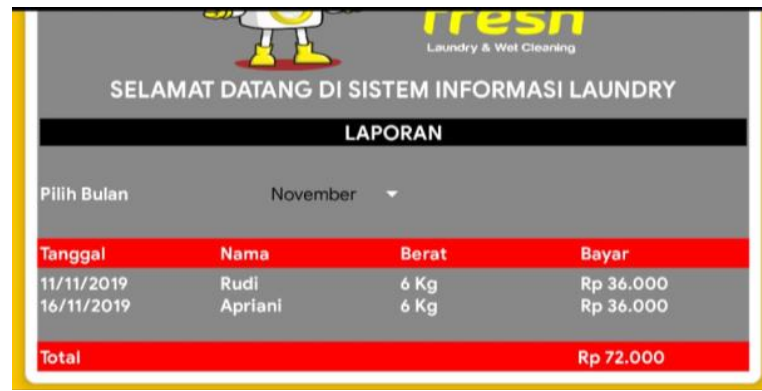

Gambar 18 Halaman Laporan 
Pengujian Sistem

Pada tahapan ini, penulis melakukan pengujian dari sistem informasi laundry yang telah dibangun. Pengujian dilakukan pada setiap proses yang terdapat pada sistem informasi laundry dengan kondisi berhasil dan gagal.

Tabel 1 Hasil Pengujian Sistem

\begin{tabular}{|c|c|c|c|c|}
\hline $\begin{array}{l}\text { Modul Yang } \\
\text { Diuii. }\end{array}$ & Eroseduc Renauijan & Masukan. & Keluaran & Kesimpulan \\
\hline $\begin{array}{l}\text { Login } \\
\text { Relaregara. }\end{array}$ & 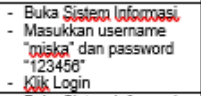 & $\begin{array}{l}\text { Username } \\
\text { "0iska" dan } \\
\text { Password } \\
\text { "123456" }\end{array}$ & 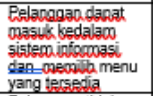 & Beshasil \\
\hline $\begin{array}{l}\text { Login } \\
\text { Reglacegar }\end{array}$ & 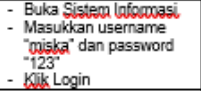 & $\begin{array}{l}\text { Username } \\
\text { "uiska" dan } \\
\text { Password "123" }\end{array}$ & 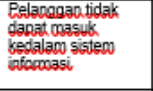 & Gaaal \\
\hline Daftar & 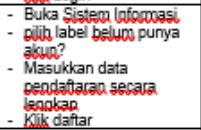 & $\begin{array}{l}\text { Data pedablacaa } \\
\text { secarad lenobara }\end{array}$ & $\begin{array}{l}\text { Proses } \\
\text { pendatataraca } \\
\text { bectassil }\end{array}$ & Berbasil \\
\hline Daftar & 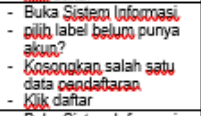 & 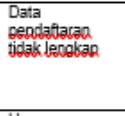 & Rendatarar a3ash & Gaal \\
\hline Login Admin & 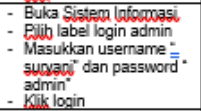 & $\begin{array}{l}\text { Username } \\
\text { "sucsaul" dan } \\
\text { Password } \\
\text { "admin" }\end{array}$ & 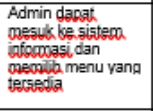 & Bescasil \\
\hline Login Admin & 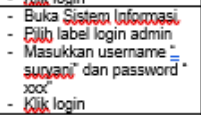 & $\begin{array}{l}\text { Username } \\
\text { "sucyail" dan } \\
\text { Password } \\
\text { "admin" }\end{array}$ & $\begin{array}{l}\text { Admin fdak dagat } \\
\text { passuk kesistera } \\
\text { iffocuasi }\end{array}$ & Gagal \\
\hline $\begin{array}{l}\text { Data } \\
\text { Iraosaksi }\end{array}$ & 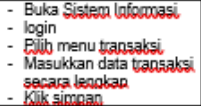 & $\begin{array}{l}\text { Data transabsi } \\
\text { secaral lengkar }\end{array}$ & $\begin{array}{l}\text { Data tanjaaksi } \\
\text { bectassil disicoosa }\end{array}$ & Benchasil \\
\hline $\begin{array}{l}\text { Data } \\
\text { Iraosaksi. }\end{array}$ & 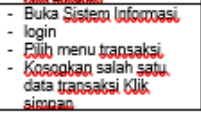 & $\begin{array}{l}\text { Data transaksi } \\
\text { fidsk leodkad }\end{array}$ & $\begin{array}{l}\text { Data transaksi } \\
\text { azazldisijobas }\end{array}$ & Gaabl \\
\hline
\end{tabular}

\section{PENUTUP}

Kesimpulan

Setelah melakukan penelitian ini, maka penulis mengambil kesimpulan mengenai perancangan sistem informasi transaksi laundry pada Simply Fresh Laundry berbasis android, yaitu :

1. Sistem informasi transaksi laundry yang telah dibangun dapat menggantikan sistem transaksi laundry yang sedang berjalan pada Simply Fresh Laundry

2. Sistem informasi transaksi laundry yang telah dibangun dapat membantu pelanggan dalam memperoleh informasi mengenai transaksi laundry yang telah dilakukan secara cepat dan mudah serta membantu admin Simply Fresh Laundry dalam melakukan proses transaksi laundry sehingga dapat menjaga hubungan baik antara pelanggan dan Simply Fresh Laundry.

3. Sistem informasi yang dibangun telah disesuaikan dengan spesifikasi smartphone android yang digunakan oleh sebagian besar masyarakat, sehingga tidak ada kendala pada saat proses instalasi dan penggunaan sistem informasi.
Saran

Saran yang diberikan penulis mengenai kegiatan penelitian yang telah dilaksanakan dan sistem informasi yang telah dibangun adalah sebagai berikut :

1. Sebaiknya programmer melakukan maintenance sistem informasi untuk menghindari terjadinya error dan kesalahan

2. Sebaiknya programmer selalu melakukan pembaharuan sistem informasi yang berorientasi pada kebutuhan user.

3. Sebaiknya admin Simply Fresh Laundry memberikan informasi transaksi laundry kepada pelanggan secara cepat dan akurat.

4. Sebaiknya programmer dapat menambahkan layanan notifikasi pada sistem informasi, jika transaksi telah selesai diproses.

5. Sebaiknya admin melakukan backup data transaksi kemedia penyimpanan eksternal

\section{REFERENSI}

[1] E. Susanto, T. H. Utami, and D. Hermanto, "Sistem Informasi Pemesanan Laundry Berbasis Android Di Kota Palembang," JATISI (Jurnal Tek. Inform. dan Sist. Informasi), vol. 5, no. 2, pp. 158-168, 2019.

[2] M. Y. Simargolang and N. Nasution, "Aplikasi Pelayanan Jasa Laundry Berbasis WEB (Studi Kasus: Pelangi Laundry Kisaran)," J. Teknol. Inf., vol. 2, no. 1, p. 9, 2018.

[3] A. Lipursari, "Peran Sistem Informasi Manajemen (Sim) Dalam Pengambilan Keputusan," Sist. Inf. Manaj., vol. 5, no. 1, pp. 26-37, 2013.

[4] T. Sutabri, Analisis Sistem Informasi. Yogyakarta: CV. Andi Offset, 2012.

[5] C. Tristianto, "Penggunaan Metode Waterfall Untuk Pengembangan Sistem Monitoring Dan Evaluasi Pembangunan Pedesaan," J. Teknol. Inf. ESIT, vol. XII, no. 01, pp. 8-22, 2018.

[6] R. S. Pressman, Rekayasa Perangkat Lunak Pendekatan Praktisi, 7th ed. Yogyakarta: CV. Andi Offset, 2012.

[7] Ruslan Efendi Nasution, "Implementation Sms Gateway In The Development Web Based Information System," Universitas Lampung, 2012.

[8] Y. Achyarudin, A. H. Zulkarnaen, and M. Rachmadi, "Sistem Informasi Akademik Berbasis Android Pada STMIK Global Informatika Multi Data Palembang," Sist. Inf. Akad. Berbas. Android Pada Stmik Glob. Inform. 
Multi Data Palembang, p. 7, 2013.

[9] Nazarudin Safaat, Pemograman Aplikasi Mobile Smartphone dan Tablet PC Berbasis Android. Bandung: Informatika, 2012.

[10] A.S. Rosa dan Shalahudin, Rekayasa Perangkat Lunak (Terstruktur dan Berorientasi Objek ). Bandung: Informatika, 2015. 